\title{
MIRROR VISUAL FEEDBACK IMPACT ON ABDUCTOR POLLICIS BREVIS MUSCLE ELECTRICAL ACTIVITY IN THE STROKE AFFECTED ARM
}

\author{
Mindaugas Kvedaras, Rima Solianik, Neringa Baranauskienė \\ Lithuanian Sports University, Kaunas, Lithuania
}

\begin{abstract}
Research background and hypothesis. Stroke is recognized as one of the major causes of morbidity, mortality and long-term disability around the world (Laver et al., 2012). Mirror visual feedback is one of the newest areas of research that shows the potential application in neurorehabilitation (Kang et al., 2012). We hypothesize that abductor pollicis brevis muscle activity in the stroke affected arm will be higher when the movements are performed with non-affected hand visual mirror feedback.

Research aim was to identify mirror visual feedback impact on abductor pollicis brevis muscle electrical activity in the stroke affected arm.

Research methods. Post-stroke subjects $(\mathrm{n}=12)$ performed bimanual thumb opposition under three conditions: without mirror visual feedback, with non-affected and affected arm reflection in the mirror. Electrical activity of abductor pollicis brevis muscle was recorded simultaniously.

Research results. There was a significantly higher $(\mathrm{p}<0.05)$ muscle activity amplitude when thumb opposition was performed with visual feedback of non-affected hand compared to task without mirror visual feedback. No muscle activity amplitude difference was observed when thumb opposition was performed looking at affected hand mirror visual feedback compared to task without mirror visual feedback. Motor unit firing rate did not differ between tasks.

Discussion and conclusions. I. Nojima and co-authors (2012) have identified that mirror visual feedback activates motor cortex. Additionally, our study shows that even during one-time movement with observation of nonaffected hand in the mirror shows higher muscle electrical activity in the affected hand.
\end{abstract}

Keywords: mirror neurones, thumb opposition, bimanual movement.

\section{INTRODUCTION}

$\mathrm{S}$ troke is recognized as one of the major causes of morbidity, mortality and longterm disability around the world. It is often irregular and varies from 100 to 300 cases for 100000 persons per year. Stroke occurs in one million people per year in Europe (Laver et al., 2012).

Stroke usually impairs motor function which disrupts the activities of daily living. It is known that $87 \%$ of upper limb motor damage occurs in acute stroke period (Yun et al., 2011). In addition, more than $50 \%$ patients suffer long-term upper limb impairments because they avoid using their affected arm after conventional therapy (Kang et al., 2012). Moreover, the thumb opposition is the most difficult and important movement of thumb in daily activities (Delagi et al., 2011). Thumb opposition, thereby grasp mechanism, is very disturbed due to abductor pollicis brevis muscle paralysis (Delagi et al., 2011).

Mirror visual feedback is one of the newest areas of research that shows the potential 
application in neurorehabilitation (Kang et al., 2012). Neuropsychological studies have observed that mirror causes conflict between vision and proprioception. It is interesting to note that vision information dominates (Holmes et al., 2004; Ro et al., 2004). The systematic review showed that mirror therapy improves hand function and activities of daily living (Thieme et al., 2013). Previous studies have suggested that visual mirror feedback increases primary motor cortex activity of the stationary hand (Garry et al., 2005; Shinoura et al., 2008; Tominaga et al., 2009) where mirror neurons exist (Dushanova, Donoghue, 2010).

J. H. Cauraugh and J. J. Summers (2005) note the importance of planning and executing bilateral movements post-stroke. It can facilitate cortical neural plasticity by these mechanisms: motor cortex disinhibition that allows increased use of the spared pathways of the damaged hemisphere, increased recruitment of the ipsilateral pathways from the contralesional or contralateral hemisphere to supplement the damaged crossed corticospinal pathways, and upregulation of descending premotorneuron commands onto propriospinal neurons (Cauraugh, Summers, 2005).

In our study we simultaneously used mirror visual feedback and bilateral movement performance, and tried to increase motor cortex excitability which results in increased muscle activation (Furukawa et al., 2012). We hypothesize that abductor pollicis brevis muscle activity in the stroke affected arm will be higher when the bilateral movements are performed with nonaffected hand visual mirror feedback compared to movements without it.

One study showed that mirror visual feedback affects stationary non-dominant hand muscle activity in healthy subjects while they observe dominant hand reflection in the mirror (Furukawa et al., 2012). We failed to find any evidence that shows the single-mirror visual feedback effect in stroke affected arm muscle electrical activity. Our research aim was to identify mirror visual feedback impact on abductor pollicis brevis muscle electrical activity in the stroke affected arm.

\section{RESEARCH METHODS}

Participants. Twelve women (age -65.51 (4.46)) with right-hemisphere stroke (28.34 (3.67) days after the first stroke symptoms) participated in the study. All participants were right-handed, according to the Edinburgh Handedness Inventory (Oldfield, 1971).

The inclusion criteria of this study include: first-ever stroke, subacute post-stroke stage within 8 weeks after onset, muscle strength in the affected hand overcome gravity (score $>3$ on the Lovett scale) (Cuthbert, Goodheart, 2007), no serious cognitive deficits (score $>20$ on the Mini Mental-State Exam) (Folstein et al., 1975), and no spasticity at any joint of the upper limb (score of $<1$ on the Modified Ashworth Scale) (Bohannon, Smith, 1987).

The subjects were familiarized with the study objectives, methods, procedures and possible inconveniences. Research was carried out in accordance with the principles of the Declaration of Helsinki, concerning ethics of the experimentation with humans. All subjects gave informed consent prior to participation.

Motor tasks performance. All subjects had to perform thumb opposition with each finger movement under three different conditions (Table). During tasks subjects were asked to supinate their forearms. During tasks which used mirrors subjects' hands were $10 \mathrm{~cm}$ apart from mirror, and without mirror hands were $25 \mathrm{~cm}$ apart from each other. Tasks priority was chosen randomly. Mirror wall $(38 \mathrm{~cm}$ x $33 \mathrm{~cm}$ ) (Figure 1) was used to perform tasks with visual mirror feedback. One minute break between tasks was done in order to avoid fatigue (Naik, 2012).

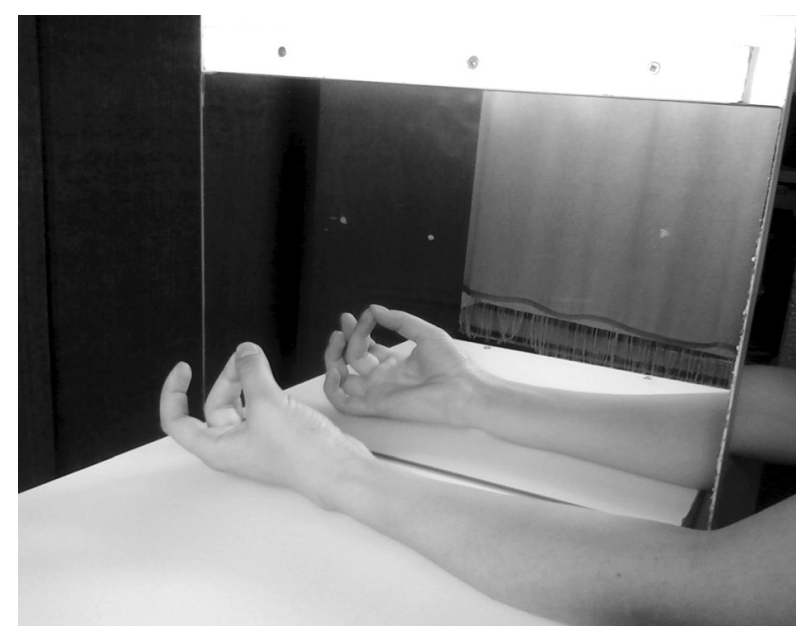

Figure 1. Mirror wall $(38 \mathrm{~cm} \times 33 \mathrm{~cm})$

Measurements of muscle electrical activity. Bipolar $\mathrm{Ag}-\mathrm{AgCl}$ surface electrodes were used for surface electromyogram (sEMG) recordings (silver bar electrodes, diameter $10 \mathrm{~mm}$, centreto-centre distance $20 \mathrm{~mm}$ ) of abductor pollicis 
Table. Tasks performed by subjects

\begin{tabular}{|c|c|c|c|}
\hline Tasks & Conditions & Repetitions (times) & Rest between the repetitions \\
\hline $\begin{array}{l}\text { Thumb opposition with non-affected } \\
\text { hand reflection (NAHR) }\end{array}$ & $\begin{array}{c}\text { Non-affected hand reflection in } \\
\text { the mirror }\end{array}$ & 3 & No rest \\
\hline $\begin{array}{l}\text { Thumb opposition with affected hand } \\
\text { reflection (AHR) }\end{array}$ & $\begin{array}{l}\text { Affected hand reflection in the } \\
\text { mirror }\end{array}$ & 3 & No rest \\
\hline $\begin{array}{l}\text { Thumb opposition without mirror } \\
\text { reflection (WR) }\end{array}$ & No mirror & 3 & No rest \\
\hline
\end{tabular}

brevis muscle belly oriented parallel to the length of fibres in the affected hand (Biometrics Ltd, Gwent, UK). The skin at the electrode site was cleaned with alcohol wipes. The ground electrode was positioned on the wrist of non-affected hand. sEMG signals were recorded by amplifiers with signal measurement using a filter bandwidth of $20-460 \mathrm{~Hz}$. The analogue signal was sampled and converted to digital form at sampling frequency of $1 \mathrm{kHz}$. The EMG signal was telemetered to a receiver that contained a differential amplifier with an input impedance of $10 \mathrm{M} \Omega$, input noise level was less than $5 \mu \mathrm{V}$ and the common mode rejection ratio was higher than $96 \mathrm{~dB}$. sEMG signals were synchronously recorded during pollicis opposition movements in all conditions. We analysed the root mean square and mean power frequency to assess muscle activity amplitude and motor unit firing rate, respectively.

Mathematical statistics. The research data were processed using Microsoft Excel 2010 program mathematical statistical analysis. The data are reported as mean values and standard deviations (SD). Changes were evaluated using Student's $(t)$ test $(p<0.05$ level of significance).

\section{RESEARCH RESULTS}

Figure 2 shows affected hand abductor pollicis brevis muscle electrical activity amplitude under three different conditions: non-affected hand mirror visual feedback $(0.35(0.09) \mathrm{mV})$, affected hand mirror visual feedback $(0.32(0.09) \mathrm{mV})$ and task without mirror visual feedback $(0.30$ $(0.09) \mathrm{mV})$. There was no significant abductor pollicis brevis muscle electrical activity amplitude difference between the non-affected and affected hand mirror visual feedback conditions. There was a significantly higher $(\mathrm{p}<0.05)$ amplitude when subjects observed the non-affected hand reflection in the mirror compared to task without mirror visual feedback, whereas there was no significant difference in amplitude when affected hand reflection was observed in the mirror compared to task without mirror visual feedback.

There was no significant difference in muscle motor unit firing rate of the abductor pollicis brevis muscle between the non-affected hand reflection (145.97 (17.63) Hz), affected hand reflection (149.47 $(17.73) \mathrm{Hz}$ ), and task without mirror visual feedback (145.84 (11.74) Hz) (Figure 3).

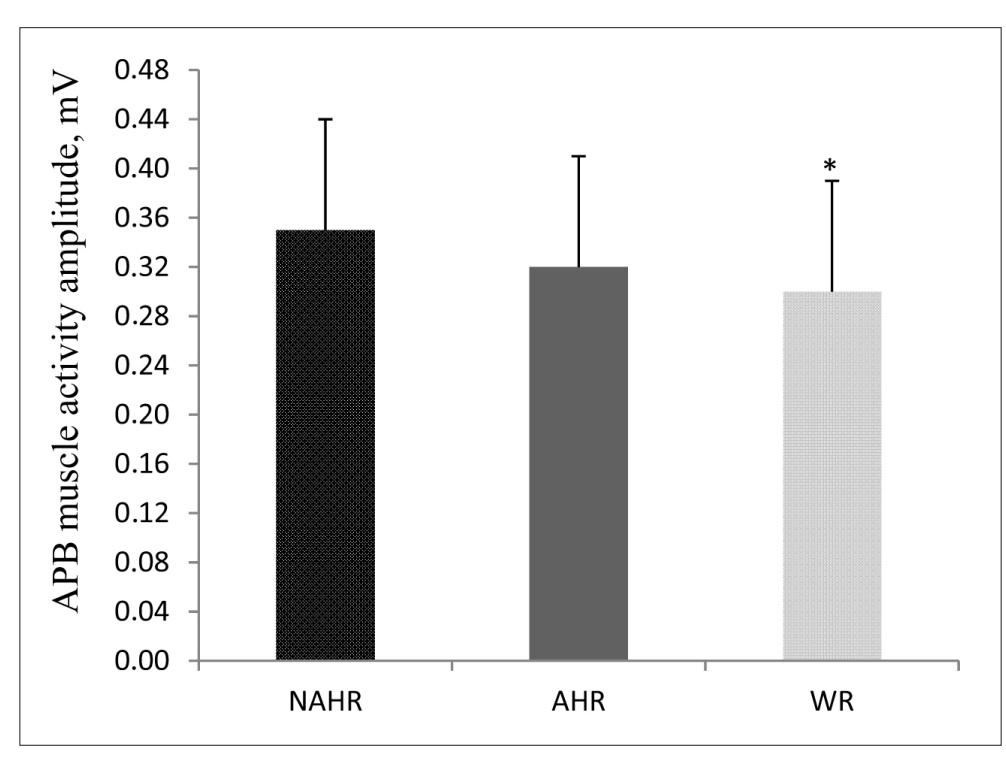

Figure 2. Stroke affected hand abductor pollicis brevis (APB) muscle electrical activity amplitude during observation of thumb opposition of the non-affected hand reflection (NAHR), affected hand reflection (AHR) and task without reflection (WR) in the mirror
Note. ${ }^{*}$ - statistically significant difference $(p<0.05)$ between NAHR and WR tasks. 
Figure 3. Stroke affected hand abductor pollicis brevis (APB) muscle motor unit firing rate during observation of thumb opposition of the non-affected hand reflection (NHR), affected hand reflection (NHR) and performing thumb opposition without reflection (WR) in the mirror

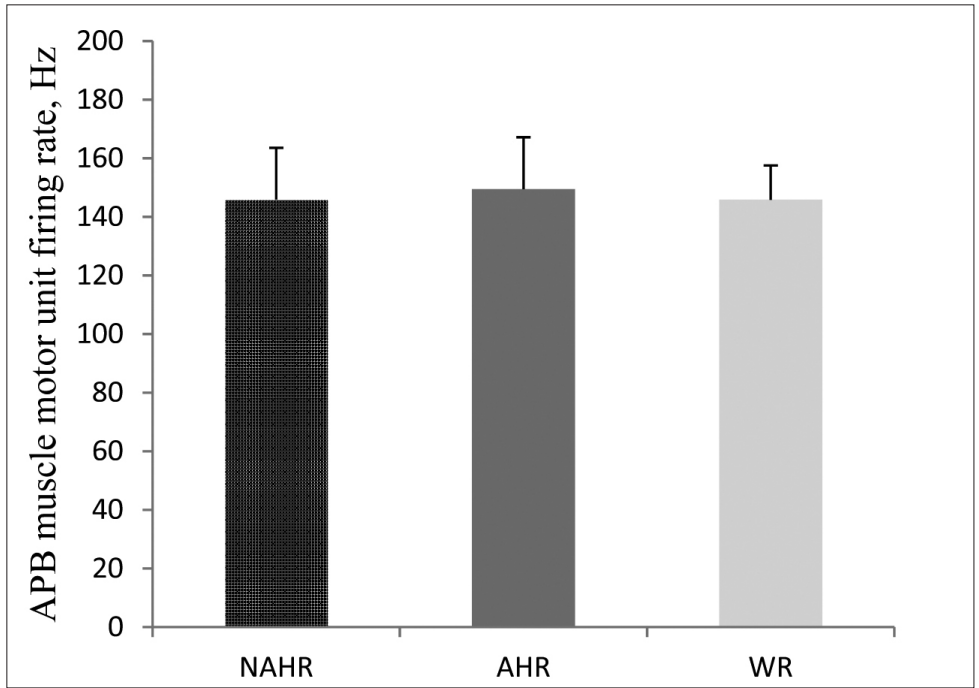

\section{DISCUSSION}

Obtained results confirmed our hypothesis that abductor pollicis brevis muscle activity in the stroke affected arm would be higher when bimanual movements were performed with healthy hand visual mirror feedback compared to observation of affected-hand and movements without mirror.

K. Furukawa and co-authors (2012) showed that mirror visual feedback increased stationary non-dominant hand muscle activity in healthy subjects while they observed dominant hand movement reflection in the mirror. Our study showed that observation of the healthy hand in the mirror increased muscle electrical activity amplitude, whereas affected hand observation did not show any differences compared to movements without mirror. Several mechanisms have been suggested to explain how mirror therapy works. E. L. Altschuler and co-authors (1999) explain that the mirror reflection of the healthy moving arm, which looks like the affected arm moving correctly, substitutes the often decreased or void proprioceptive input, thus helping recruit the premotor cortex and improve motor rehabilitation through close interaction with the premotor cortex. I. Nojima and co-authors (2012), M. I. Garry and co-authors (2005) performed transcranial magnetic stimulation during mirror illusion in healthy subjects and showed increased excitability of the primary motor cortex (M1) of the hand behind the mirror. In addition, J. Liepert and co-authors (2001) reported that the primary motor cortex was excited by hand movements and thus the ipsilateral M1 excitability is known to increase contraction strength as voluntary unilateral arm/hand movements induced excitability changes in both the contralateral and ipsilateral M1.

X. Hu and co-authors (2012) observed reduced firing rates evident in the paretic muscle compared with the contralateral muscle of stroke subjects. However, the motor unit firing rate did not differ between different conditions. L. A. C. Kallenber and H. J. Hermens (2008) discusses that motor unit firing rates reflects CNS input solely. Possible explanations is that opposition movement is influenced not only by CNS, but also by peripheral muscle properties (Kallenber, Hermens, 2008), which can be seen on increased muscle activation amplitude.

Based on the obtained results and the completed research (Yavuzer et al., 2008; Michielsen et al., 2011; Yun et al., 2011) we indicate the importance of mirror visual feedback adjustment for stroke patients when the movement is performed bimanually, observing the healthy hand movements in the mirror.

\section{CONCLUSIONS AND PERSPECTIVES}

Our research aim was to identify healthy hand mirror visual feedback impact on abductor pollicis brevis muscle electrical activity in the stroke affected arm. The main findings of our study are:

1. Muscle electrical activity amplitude of affected hand with non-affected hand mirror visual feedback was higher compared to movements without mirror visual feedback; 
2. Muscle electrical activity amplitude of the affected hand with its mirror visual feedback did not differ compared to movements without mirror visual feedback;

3. The rate of motor unit firing remained unchanged during all three conditions.
Subsequent studies should clarify the onetime mirror feedback effect on different types of exercises. Additionally, it is important to reveal if subjects at different stroke stages have different responses to mirror feedback.

\section{REFERENCES}

Altschuler, E. L., Wisdom, S. B., Stone, L. et al. (1999). Rehabilitation of hemiparesis after stroke with a mirror. Lancet, 353, 2035-2036.

Bohannon, R., Smith, M. (1987). Interrater reliability of a modified Ashworth scale of muscle spasticity. Physical Therapy, 67, 206-207.

Cauraugh, J. H., Summers, J. J. (2005). Neural plasticity and bilateral movements: A rehabilitation approach for chronic stroke. Progress in Neurobiology, 75 (5), 309-320.

Cuthbert, S. C., Goodheart, G. J. (2007). On the reliability and validity of manual muscle testing: A literature review. Chiropractic \& Osteopathy, 15, 4.

Delagi, E. F., Iazzetti, J., Perotto, A. O. (2011). Anatomical Guide for the Electromyographer. Springfield: Charles C Thomas. Publisher, Ltd. P. 8-11.

Dushanova, J., Donoghue, J. (2010). Neurons in primary motor cortex engaged during action observation. European Journal of Neuroscience, 31 (2), 386-398.

Folstein, M. F., Folstein, S. E., McHugh, P. R. (1975). "Mini-mental State." A practical method for grading the cognitive state of patients for the clinician. Journal of Psychiatric Research, 12, 189-198.

Furukawa, K., Suzuki, H., Fukuda, J. (2012). Motion of the drawing hand induces a progressive increase in muscle activity of the non-dominant hand in Ramachandran's Mirror-Box therapy. Journal of Rehabilitation Medicine, 44 (11), 939-943.

Garry, M. I., Loftus, A., Summers, J. J. (2005). Mirror, mirror on the wall: Viewing a mirror reflection of unilateral hand movements facilitates ipsilateral M1 excitability. Experimental Brain Research, 163, 118-122.

Holmes, N. P., Crozier, G., Spence, C. (2004). When mirrors lie: 'Visual capture' of arm position impairs reaching performance. Cognitive, Affective \& Behavioral Neuroscience 4, 193-200.

Hu, X. Suresh, A. K., Li, X., Rymer, W. Z., Suresh, N. L. (2012). Impaired motor unit control in paretic muscle post stroke assessed using surface electromyography: A preliminary report. Conference proceedings: IEEE Engineering in Medicine and Biology Society, (pp. 4116-4119).

Kallenberg, L. A., Hermens, H. J. (2008). Behaviour of a surface EMG based measure for motor control: motor unit action potential rate in relation to force and muscle fatigue. Journal of Electromyography \& Kinesiology, 18 (5), 780-788.

Kang, Y. J., Park, H. K., Kim, H. J. et al. (2012). Upper extremity rehabilitation of stroke: Facilitation of corticospinal excitability using virtual mirror paradigm. Journal of NeuroEngineering and Rehabilitation, 9, 71.

Laver, K., George, S., Thomas, S. et al. (2012). Cochrane review: virtual reality for stroke rehabilitation. European Journal of Physical Rehabilitation \& Medicine, 48, 523-530.

Liepert, J., Dettmers, C., Terborg, C. et al. (2001). Inhibition of ipsilateral motor cortex during phasic generation of low force. Clinical Neurophysiology, 112, 114-121.

Michielsen, M. E., Selles, R. W., van der Geest, J. N. et al. (2011). Motor recovery and cortical reorganization after mirror therapy in chronic stroke patients: A phase II randomized controlled trial. Neurorehabilitation \& Neural Repair, 25 (3), 223-233.

Naik, G. R. (2012). The Usefulness of Mean and Median Frequencies in Electromyography Analysis. In A. Phinyomark, S. Thongpanja, H. Hu et al., Computational Intelligence in Electromyography Analysis - A Perspective on Current Applications and Future Challenges (pp. 195-220). Rijeka: InTech.

Nojima, I., Mima, T., Koganemaru, S. et al. (2012). Human motor plasticity induced by mirror visual feedback. Journal of Neuroscience, 32, 1293-1300.

Oldfield, R. C. (1971). The assessment and analysis of handedness: The Edinburgh inventory. Neuropsychologia, 9, 97-113.

Ro, T., Wallace, R., Hagedorn, J. et al. (2004). Visual enhancing of tactile perception in the posterior parietal cortex. Journal of Cognitive Neuroscience, 16, 24-30.

Shinoura, N., Suzuki, Y., Watanabe, Y. et al. (2008). Mirror therapy activates outside of cerebellum and ipsilateral M1. NeuroRehabilitation, 23, 245-252.

Thieme, H., Mehrholz, J., Pohl, M. et al. (2013). Mirror therapy for improving motor function after stroke. Stroke, 44 (1), e 1-2.

Tominaga, W., Matsubayashi, J., Deguchi, Y. et al. (2009). A mirror reflection of a hand modulates stimulusinduced 20-Hz activity. Neuroimage, 46, 500-504.

Yavuzer, G., Selles, R., Sezer, N. et al. (2008). Mirror therapy improves hand function in subacute stroke: A randomized controlled trial. Archives of Physical Medicine and Rehabilitation, 89, 393-398.

Yun, G. J., Chun, M. H., Park, J. Y. (2011). The synergic effects of mirror therapy and neuromuscular electrical stimulation for hand function in stroke patients. Annals of Rehabilitation Medicine, 35, 316-321. 


\title{
VEIDRODINIO GRIZŽTAMOJO RYŠIO POVEIKIS PATYRUSIŲJŲ GALVOS SMEGENŲ INSULTĄ PAŽEISTOS RANKOS TRUMPOJO ATITRAUKIAMOJO NYKŠČIO RAUMENS ELEKTRINIAM AKTYVUMUI
}

\author{
Mindaugas Kvedaras, Rima Solianik, Neringa Baranauskienė \\ Lietuvos sporto universitetas, Kaunas, Lietuva
}

\begin{abstract}
SANTRAUKA
Tyrimo pagrindimas ir hipotezė. Galvos smegenų insultas yra pripažintas kaip viena iš pagrindinių sergamumo, mirtingumo ir ilgalaikès negalios priežasčiu visame pasaulyje (Laver et al., 2012). Veidrodinis grižtamasis ryšys yra viena iš naujausių tyrimu sričių, kuri taikoma neuroreabilitacijos metu (Kang et al., 2012). Manytume, kad dèl insulto pažeistos rankos trumpojo atitraukiamojo nykščio raumens elektrinis aktyvumas yra didesnis atliekant judesius veidrodinio grižtamojo ryšio principu nei be jo.

Tikslas - nustatyti veidrodinio grižtamojo ryšio poveiki patyrusiuju galvos smegenų insultą pažeistos rankos trumpojo atitraukiamojo nykščio raumens aktyvumui.

Metodai. Asmenys, patyrę galvos smegenų insultą ( $(n=12)$, atliko abiejų rankų nykščiu priešpastatymo judesi esant trims skirtingoms sąlygoms: judesiai atliekami be veidrodinio grižtamojo ryšio, judesiai atliekami stebint sveikosios ir pažeistosios rankos atvaizdą veidrodyje. Užduočių metu buvo registruojamas trumpojo atitraukiamojo nykščio raumens elektrinis aktyvumas.

Rezultatai. Stebint sveikos rankos atspindi veidrodyje nustatyta reikšmingai didesnè $(p<0,05)$ raumens elektrinio aktyvumo amplitudè, lyginant su rodikliais judesių, atliekamų be veidrodžio. Stebint pakenktos rankos atspindị veidrodyje, amplitudè reikšmingai nesiskyré nuo judesiu, atliekamų be veidrodžio. Trumpojo atitraukiamojo nykščio raumens motoriniu vienetu impulsavimo dažnumas atliekant skirtingas užduotis nesiskyrè.

Aptarimas ir išvados. I. Nojoma ir bendraautoriai (2012) teigia, kad veidrodinis grižtamasis ryšys aktyvuoja motorinę žievę. Mūsų tyrimas parodè, kad netgi vienkartinis judesys stebint sveikos rankos atspindį veidrodyje padidina pažeistos rankos trumpojo atitraukiamoojo nykščio raumens elektrinį aktyvumą.
\end{abstract}

Raktažodžiai: veidrodiniai neuronai, nykščio priešpastatymas, judesys abiem rankomis. 